\title{
Off to market: but which one? Understanding the participation of small-scale farmers in short food supply chains-a Hungarian case study
}

\author{
Zsófia Benedek ${ }^{1} \cdot$ Imre Fertő $^{1,2} \cdot$ Adrienn Molnár ${ }^{1,3}$
}

Accepted: 22 September 2017 / Published online: 23 October 2017

(c) The Author(s) 2017. This article is an open access publication

\begin{abstract}
The research described in this paper was designed to identify the factors that influence the importance small-scale farmers place on different marketing channels of short food supply chains. The focus concerns two entirely different types of market that are present in the bigger cities in Hungary: 'conventional' markets where there are no restrictions on locality but the farmer-market relationship is based on binding contracts, and newly-emergent farmers' markets at which only local growers can sell ad hoc, using their own portable facilities. Results are based on a survey that was conducted in 2013 among 156 Hungarian market oriented farmer-vendors at different types of market and confirm that different markets are visited by different types of farmers. Farmers who favour conventional markets are typically less educated, operate on smaller scales and are more committed to their chosen markets via long-term contracts (which reduce the probability of their trying other outlets). The preference for farmers' markets is stronger with farmers who are more open to cooperation, have specific investment plans for developing their farms and among those who are specifically looking to directly interact with their customers to avoid middlemen. The relevance of the findings is highlighted by the ongoing Short Food Supply Chain Thematic Sub-programme in the present European Union financing period; farmers' profiles in any given marketing channel must be understood if short food supply chains are to be effectively promoted. Different types of small-scale farmers will benefit from different supporting frameworks, interventions, and initiatives.
\end{abstract}

Keywords Local food systems $\cdot$ Farmers' markets $\cdot$ Discrete choice model $\cdot$ Transaction Cost Theory $\cdot$ Hungary

$\begin{array}{ll}\text { Abbreviations } \\ \text { CEE } & \text { Central and Eastern European } \\ \text { CM } & \text { Conventional market } \\ \text { CSO } & \text { Central statistical office } \\ \text { D } & \text { Dummy variable }\end{array}$

Zsófia Benedek

benedek.zsofia@krtk.mta.hu

Imre Fertő

ferto.imre@krtk.mta.hu

Adrienn Molnár

Adrienn.Molnar@UGent.be

1 Institute of Economics, Centre for Economic and Regional Studies, Hungarian Academy of Sciences, Tóth Kálmán u. 4, Budapest 1097, Hungary

2 University of Kaposvár, Guba Sándor utca 40, Kaposvár 7400, Hungary

3 Department of Agricultural Economics, Ghent University, Coupure links 653, Ghent 9000, Belgium

$\begin{array}{ll}\text { EU } & \text { European Union } \\ \text { FM } & \text { Farmers' market } \\ \text { GDP } & \text { Gross domestic product } \\ \text { H } & \text { Hypothesis } \\ \text { NUTS } & \begin{array}{l}\text { Nomenclature des unités territoriales statistiques } \\ \text { (Classification of Territorial Units for Statistics) }\end{array} \\ \text { OM } & \text { Organic market } \\ \text { SFSC } & \text { Short food supply chain } \\ \text { TCE } & \text { Transaction cost economics }\end{array}$

\section{Introduction}

The globalisation of food production and the rapid rise of supermarkets have led to adjustment problems for smallscale farmers when they have attempted to join conventional food systems (Dries et al. 2004; Watts et al. 2005; Ilbery et al. 2006; Burch et al. 2013). The retail sectors of Central and Eastern European (CEE) countries have experienced profound and exceptionally rapid transformation (Dries et al. 
2004; Swinnen and Maertens 2007; Csáki and Forgács 2008) that have created further challenges for farmers, especially in sectors in which small enterprises dominate (Bakucs et al. 2012). The involvement of small-scale farmers in alternative food systems may be an effective response to these challenges (Renting et al. 2003; Lawson et al. 2008; Blay-Palmer et al. 2013).

This paper focuses on Hungary where alternative food systems, similarly to in other CEE countries (for examples see Juska et al. 2005; Borec and Prišenk 2013; Spilková et al. 2013; Renko et al. 2014), are attracting particular attention (Balázs 2012; Juhász 2012). In line with the intentions (and wording) of the European Union (EU), 'short food supply chains' (SFSCs), clear examples of alternative food systems, which are characterized by their lack of middlemen and potentially offer farmers greater returns (Martinez et al. 2010; Kneafsey et al. 2013), is a key concept in the National Focus in the Rural Development Programme (2014-2020). The Hungarian government is dedicated to supporting smallscale farmers through the promotion of SFSCs, among other measures. For instance, the legal environment has changed positively in the past few years: for example, local food public procurement initiatives can now be launched more easily and regulations concerning the opening of farmers' markets are now less rigorous (Balázs 2012; Benedek et al. 2014). Further, with respect to the reform of the Common Agricultural Policy of the EU, a Short Food Supply Chain Thematic Sub-programme has been launched in Hungary which emphasises the need for research input. Farmers' profiles in any given marketing channel must be understood if short food supply chains are to be effectively promoted and to meet the ultimate goal of the Rural Development Programme: to ensure the viability of farmers through the rise of their potential for increasing profits.

As such, the outcomes of this research are of clear interest for Hungarian policy making, but in addition to that the paper might be of interest from an academic perspective as well. First, it provides details from a CEE country. Knowledge of the development of local food systems in postsocialist countries compared to traditional market economies, is still limited, in spite of the fact that some patterns and processes are remarkably different. For instance, food self-provisioning is more widespread in general (Jehlička and Smith 2011); and much less a recreational activity but rather a survival strategy in some CEE countries (Alber and Kohler 2008; Mincyte 2011), while serves as a hobby and as a way of obtaining healthy food in others (Jehlička et al. 2013). Also, semi-subsistence farming faces marginalisation in the confronting rural and social development programmes of CEE countries (Mincyte 2011). Second, this paper describes different types of market in Hungary, and quantitatively compares farmers visiting these markets. The number of examples for comparative studies focusing on vendors of various types of short chains is still limited due to the difficulties connected to the collection of comparable data (Kneafsey et al. 2013), especially, when quantitative studies are involved (e.g. Hardesty and Leff 2010; for qualitative examples see e.g.; Hinrichs 2000; Brown and Miller 2008; Kneafsey et al. 2013).

This paper describes research which was designed to identify the factors that influence Hungarian small-scale farmers' decisions concerning selected alternative food systems (different types of market) using survey data. More precisely, the research questions are the following: (1) which farmers choose which market; and (2) how do farmer and farm- and production-related characteristics influence the decision of farmers about their preference for markets?

\section{The local context}

It is not easy to define short food supply chains (Martinez et al. 2010; Kneafsey et al. 2013). Most definitions stress that locality, a direct relationship between farmers and consumers and higher quality are important features (Renting et al. 2003; Maye and Kirwan 2010). SFSCs typically involve the use of various marketing channels (Renting et al. 2003; Watts et al. 2005; Jarosz 2008). Although most farmers use several marketing channels for direct selling in parallel (Lass et al. 2003; Brown and Miller 2008), there is typically one dominant mode in terms of volumes sold; among Hungarian small-scale farmers this involves selling at markets (Juhász 2012).

There are different types of market in Hungary. Conventional markets and market halls (CMs) have a long history in Hungarian communities. At CMs retail operations predominate, although a smaller area is usually dedicated to individual farmers (who are typically licensed and registered as small-scale agricultural producers). These markets are maintained by local governments which provide the farmers with all the (permanent) facilities needed for them to make sales, such as tables. There are typically no restrictions about the provenance (geographical location) of the farm or the produce. Typically, CMs make long-term rental contracts with their farmers: the length of a contract is usually one year and gives the farmer the right to rent a specified table for the contractually-agreed-on price if they arrive at the market within one hour of its opening. There are several types of legal arrangements but fees are typically paid even if a farmer decides not to show up. Unoccupied tables may be rented on a daily basis on a first-come, first-served basis for a price typically much higher than if contracted for in advance. Theoretically, the number of tables rented out on a pre-contracted basis limits ad hoc selling but in practice only the most popular markets run out of tables, and then only on specific days (Saturday is typically the busiest market day) (Anikó Juhász, personal communication, 25/03/2015). 
The occurrence of 'western type' farmers' markets (FMs), with their strict restrictions on farm locality (Ilbery et al. 2006; Kneafsey et al. 2013) - in Hungary, farms must be located within $40 \mathrm{~km}$ of the market-is a relatively new phenomenon. FMs (under the term 'local producers' markets') are specifically defined in Act CLXIV of 2005 on Trade. Legal regulation concerning the opening and maintenance of FMs was clarified and relaxed in 2012; correspondingly, there has been a significant increase in the number of FMs, especially in bigger cities and at popular holiday resorts such as the Balaton region. FMs are typically run by non-governmental organizations or individuals. At FMs only an area for selling and a supply of electricity is provided to the farmer; all other (temporary, portable) facilities such as tables, awnings, fridges, etc. must be brought in by farmers. No rental contracts are usually deployed at FMs, but farmers pay a market entrance fee (on a per-day basis). The two types of market are systematically compared in Table 1.

The third type of market is an organic market (OM) for which organic certification is required in order to sell (this applies both to retail companies and farmers). Similarly to other small-scale farmers, organic farmers who operate from their own farms need to register themselves as small-scale agricultural producers for reasons of taxation.

CMs and FMs are the most popular marketing channels in terms of absolute number, number of participating farmers and potential profit ${ }^{1}$ (Juhász 2012); moreover, they are open to every small-scale farmer (there are no additional requirements for participation such as certification). Accordingly, CMs and FMs are the focus of this paper.

\section{Related literature and hypotheses}

According to the Transaction Cost Economics (TCE) theory, a governance structure refers to the manner in which transactions are organized within the supply chain. The TCE theory starts from the assumptions of bounded rationality and opportunism and its main objective is to assign a tailormade governance structure that reduces transaction costs (Williamson 1979; James 2000; Schweitzer et al. 2011). Further, it describes supply chain relationships in line with three criteria: asset specificity, uncertainty, and frequency (Gassenheimer et al. 1994; Sharma and Sheth 1997). According to the TCE theory, greater asset specificity, uncertainty, and frequency cause greater transaction costs. The need to decrease transaction costs drives the use of a tailor-made governance structure from a continuum with spot market and vertical integration as the two extremes. The theoretically grounded classification of Gellynck and Molnár (2009) uses the following seven interrelated governance structures

\footnotetext{
${ }^{1}$ Evidence shows that prices at FMs are higher than prices at CMs (Benedek et al. 2014).
}

forming a continuum (John and Weitz 1988; Noordewier et al. 1990; Sporleder 1992; Henderson 1994; Peterson et al. 2001): spot market, non-contractual relationship $p$ with nonqualified partner, non-contractual relationship with qualified partner, contractual relationship, relation-based alliance, equity-based alliance and vertical integration (Williamson 1973; Webster 1992; Peterson et al. 2001; Raynaud et al. 2005; Schulze et al. 2006). The variables determining governance structures (i.e. determining where we are on the continuum) are: "irrelevance of identity" (Raynaud et al. 2005), "length" (Macneil 1978; Noordewier et al. 1990; Gardner et al. 1994; Jagdev and Thoben 2001; Claro et al. 2004; Raynaud et al. 2005; Trent 2005) "ex-ante restriction on the choice of the partner" (Raynaud et al. 2005), "written contract" (Jagdev and Thoben 2001; Lu et al. 2006), "contract specifications" (Jagdev and Thoben 2001; Raynaud et al. 2005), "resource sharing" (Webster 1992; Jagdev and Thoben 2001; Trent 2005), "joint forces for mutual benefits" (Macneil 1978; Noordewier et al. 1990; Jagdev and Thoben 2001; Trent 2005) "focus of control" and "intensity of control" (Noordewier et al. 1990; Gardner et al. 1994; Peterson et al. 2001) as used by Gellynck and Molnár (2009).

In order to determine the governance structure between farmers and CMs, and farmers and FMs (i.e. in order to determine where farmer-CM and farmer-FM relationships are on the continuum), the systematic comparison of $\mathrm{CMs}$ and FMs presented in Table 1 is set against the variables presented above. Due to the differences in the specific characteristics, especially as CMs are marked by contracting while FMs are not, the two market types can be regarded as different governance mechanisms. With most respect, FMs seem to be located at the "spot market" end, while CMs are closer to "vertical integration"; in spite of the fact that the identity of the partners (geographical location of the farms) matters in the farmer-FM relationship.

Thus, the questions 'which farmers choose which market (which governance structure)', and 'how do farmer, farmand production-related characteristics influence the decision of farmers about their preference of market (governance structure)' emerge. The TCE theory allows us to seek answer to the question concerning the advantage of FMs that explains their appearance and popularity. The following hypotheses are generated (Table 2):

The TCE theory emphasises the role of market related asset specificity in the choice of governance structure. In the case of this research, being committed to a certain type of market through engagement in a contract, or having regular customers, is expected to be an exit barrier and thus have a positive impact, especially in the case of a preference for CMs (hypothesis H1) (Ouma et al. 2010; Saenger et al. 2013). As participation in FMs is typically free of binding contracts, it is hypothesised that having a contract will negatively affect the preference for participating at an FM (H1b) . 


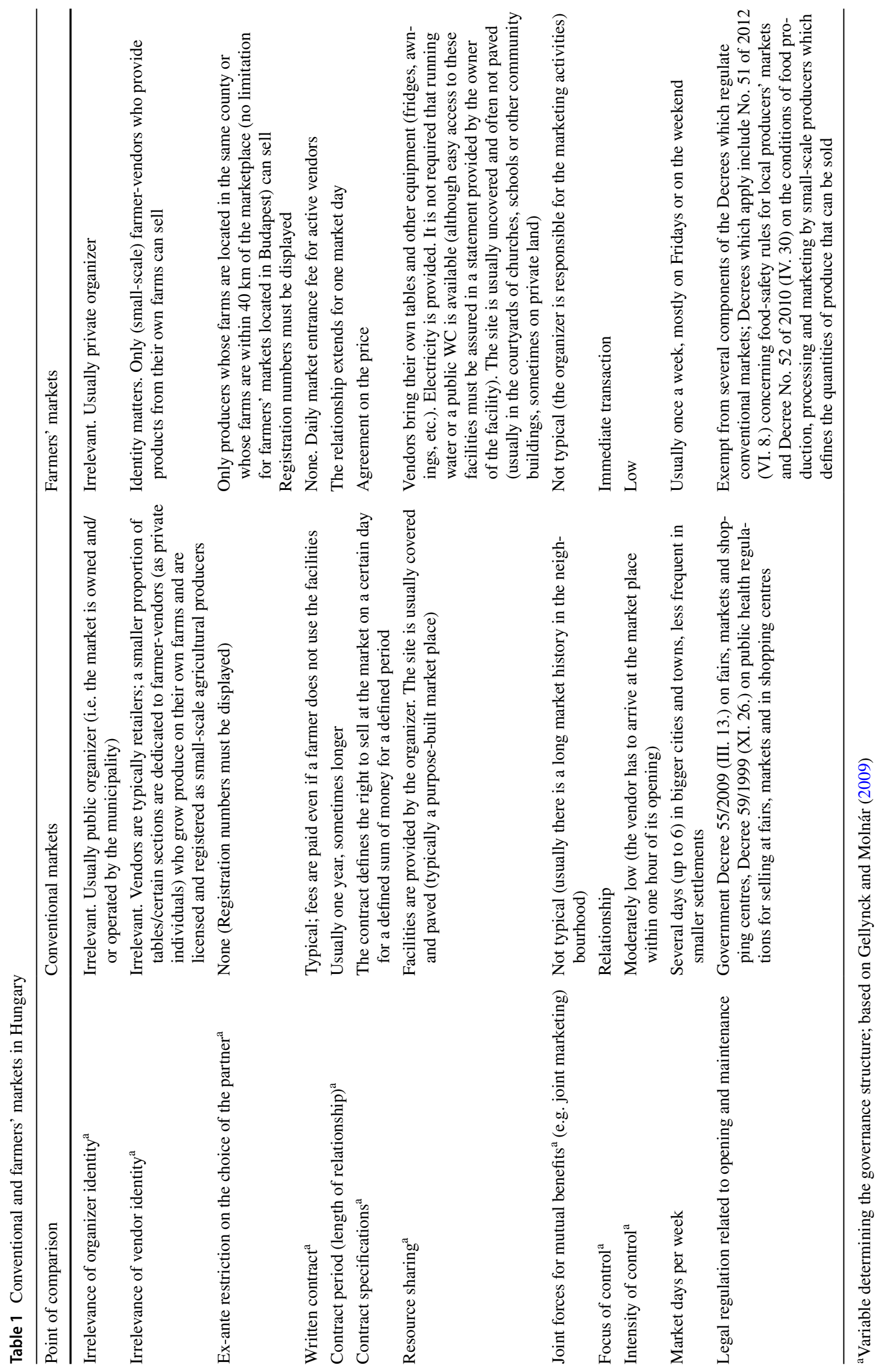


Table 2 Hypotheses on expected impact on the preferences for selling at conventional markets and farmers' markets

\begin{tabular}{|c|c|c|c|}
\hline \multicolumn{2}{|c|}{ Hypothesis } & $\begin{array}{l}\text { Conventional } \\
\text { markets }\end{array}$ & Farmers' markets \\
\hline \multicolumn{4}{|c|}{ Market-related asset-specificity } \\
\hline H1a & Transaction costs: contracts & Positive & Negative \\
\hline $\mathrm{H} 1 \mathrm{~b}$ & Transaction costs: regular customers & Positive & Positive \\
\hline \multicolumn{4}{|c|}{ Farmer-specific characteristics } \\
\hline $\mathrm{H} 2 \mathrm{a}$ & Age, experience & Positive & Negative \\
\hline $\mathrm{H} 2 \mathrm{~b}$ & Education & Negative & Positive \\
\hline \multicolumn{4}{|c|}{ Openness and nature of future expectations } \\
\hline $\mathrm{H} 3 \mathrm{a}$ & 'Openness': involved in informal partnerships & $\begin{array}{l}\text { No a priori expec- } \\
\text { tations }\end{array}$ & $\begin{array}{l}\text { No a priori } \\
\text { expectations }\end{array}$ \\
\hline $\mathrm{H} 3 \mathrm{~b}$ & 'Openness': future-orientation & Negative & Positive \\
\hline \multicolumn{4}{|c|}{ Motivation } \\
\hline $\mathrm{H} 4 \mathrm{a}$ & Motivation: more profit via direct selling & Positive & Positive \\
\hline $\mathrm{H} 4 \mathrm{~b}$ & Motivation: prompt payment & Positive & Positive \\
\hline \multicolumn{4}{|c|}{ Farm and production-specific characteristics } \\
\hline $\mathrm{H} 5 \mathrm{a}$ & Farm size & Negative & Positive \\
\hline $\mathrm{H} 5 \mathrm{~b}$ & Farm diversification & Negative & Positive \\
\hline
\end{tabular}

The rest of the hypotheses refer to general farmer-, farm-, and production-specific characteristics. Although the age of the average farmer is increasing throughout Europe, raising the issue of generational turnover (Carbone and Subioli 2011; Möllers et al. 2011), there is growing evidence that farmers who are involved in direct selling are younger, more educated and experienced and consequently more open and future-oriented than average (Lang 2010; Martinez et al. 2010; Kneafsey et al. 2013). ${ }^{2}$ However, some results imply that market-oriented farmers tend to be older than farmers who work within other alternative food systems (Brown 2002; Lass et al. 2003; Juhász 2012; Kneafsey et al. 2013). CMs are regarded as being more conventional (having longer history and being closer to mainstream, conventional food systems); accordingly, the hypothesis is that these factors will influence farmers' decision to participate in different types of market (governance structures) (H2 and H3).

The effect of motivation is also analysed in this paper. As the desire to make a greater profit is often reported to be a very important factor that drives farmers to participate in SFSCs (Kirwan 2006; Kneafsey et al. 2013), its positive influence on the decision to participate in SFSCs and choose corresponding governance structure hypothesised for both

\footnotetext{
${ }^{2}$ Hungarian farmers (similarly to farmers from other post-soviet countries) have an extremely low willingness-to-cooperate (Bakucs et al. 2012). Therefore, the ones who actively participate in informal (less regulated) partnerships can be regarded as being the most openminded farmers. Future-orientation (pro-active behaviour, which is also characteristic of open-mindedness) is similarly rare. This is also possibly a legacy issue remaining from the soviet period when the paternalistic state arranged everything for its citizens; see Bakacsi et al. 2002).
}

types of market (H4a). Similarly, delays in payment which are typical of longer supply chains drive many small-scale farmers to seek out ways of more directly interacting with consumers (Cungu et al. 2008), thus expectations of prompt payment are expected to have a positive effect on SFSC participation in general and on choosing governance structure that facilitates this in particular (H4b).

Although it is typically small-scale farmers who participate in SFSCs and choose governance structures accordingly (Lass et al. 2003; Jarosz 2008; Juhász 2012; Kneafsey et al. 2013), evidence shows that FM farmers farm larger areas, while CM farmers operate on a smaller scale (Benedek et al. 2014), following commercially-oriented semi-subsistence farming practices (Davidova et al. 2009). In this paper the effect of farm size is tested; it is expected to be negative for CM, and positive for FM farmers (hypothesis H5a). Selling through SFSCs and opting for governance structures represented by SFSCs requires the implementation of a diversification strategy (Aubert 2015). Innovative and educated FM farmers are thought to be more liable to attempt to identify different market-based survival strategies (Omamo 1998; Meert et al. 2005), thus also be more open to diversification (hypothesis H5b).

\section{Materials and methods}

\section{Survey and sample selection}

The survey was conducted from April to June, 2013. In order to ensure broad representation, markets of different size (see Table 7 in the "Appendix") and cities differently 
positioned in the settlement hierarchy were chosen. Budapest is the capital of Hungary with a population of 1.7 million and the country's highest purchasing power (the per capita GDP as a percentage of the national average was $220 \%$ in 2011; CSO 2012). Debrecen is the second biggest city in Hungary with 207,000 inhabitants and the capital of Hajdú-Bihar County (a NUTS3 region). Tura is a small town of 8000 inhabitants in Pest County. The single market of Tura is involved in the final analysis, as, although there is no similar outlet in the little town for farmers to choose to sell at, they could decide to transport their produce directly to Budapest. ${ }^{3}$

Data were also collected at organic markets as organic small-scale farmers can choose to attend non-organic markets, too (results show that this was true of 7 of 21 certified organic farmers). Farmers' markets are considered to be the competitors of organic markets by organic farmers in Hungary due to their high quality products and much lower prices (Benedek et al. 2014). As a result, it might be a viable strategy for some organic farmers to reduce their prices but sell more products at FMs.

There exists no official (government-collected) data about Hungarian markets. As the total population is unknown, the survey cannot be representative. Nevertheless, due to the careful sample selection, results might be of interest for planning and decision making purposes.

Selection of markets was based on the market database of the Research Institute of Agricultural Economics, Budapest. The database was compiled as part of a research project that was carried out in mid-2012 (after which the number of FMs started to increase steadily), so further data were collected through an internet search using the keywords 'farmers' market' plus 'city name' (in Hungarian). ${ }^{4}$ The final sample included 12 markets in Budapest, 7 in Debrecen and 1 in Tura. To the best of our knowledge, all the food markets in Debrecen and Tura were visited, and an estimated $20 \%$ of all markets located in Budapest. During selection of the Budapest-markets, three factors were accounted for: (1) the proportion of organic markets in our sample corresponds to the proportion of organic markets in Budapest (an estimated 8\%); (2) The uneven population distribution in the two major parts of the capital was noted and also corrected for purchasing power (data

\footnotetext{
${ }^{3}$ Results show that farmers arrive at the Tura market from within a radius of $8.1 \mathrm{~km}$. The distance from the capital is approximately 50 $\mathrm{km}$, while in the sample the average distance that farmers travel from their farms to the (non-organic) markets in Budapest proved to be an average $59.6 \mathrm{~km}$.

${ }^{4}$ New and newly-opening FMs in Hungary rely heavily on online and social media making them easy to find using the selected keywords.
}

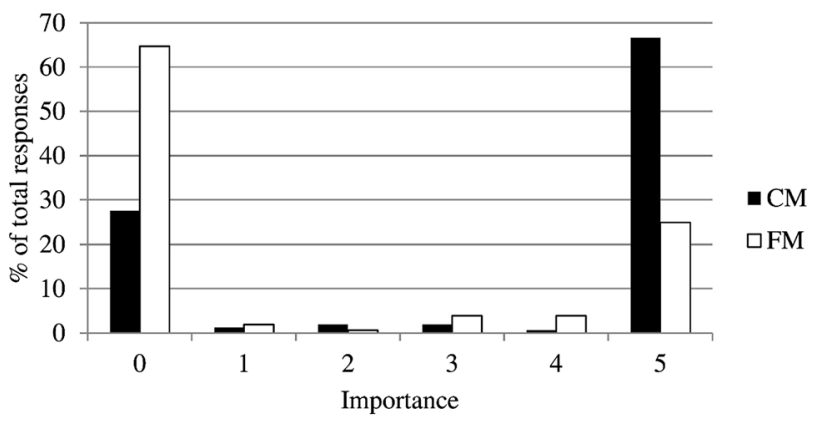

Fig. $1 \mathrm{Bi}$-modal distribution of responses related to focal types of market ( $C M$ conventional market, $F M$ farmers' market)

refer to 2013). The smaller but wealthier Buda accounts for approximately $35 \%$ of purchasing power of the capital (and thus the markets in our sample), while Pest is more populated but economically less favoured $(65 \%)$; (3) The opening days of the markets were taken into account: some markets are open six days per week, some only on workdays (or only on one day on the weekend), while some are open once during the week and once during the weekend. The final sample was designed to incorporate markets with all the possible opening-time variants. It is assumed that markets that are held less often than once a week are less important in terms of food purchasing and everyday food supply; in these cases a 'festival spirit' and the procurement of speciality products are more important. Further site selection was random. Table 7 in the "Appendix" includes a description of the basic characteristics of the markets that were involved in the research.

Only licensed and registered farmers were surveyed at the selected markets; respondents were approached randomly.

\section{Key variables}

Respondents were asked to give their opinion of the importance of the marketing channels they use, according to the income they generate. A five-level Likert scale was used (1: I occasionally sell this way; 5 : this marketing channel is very important to me; I sell most produce this way. A value of zero was assigned $a$ posteriori if a marketing channel was not mentioned at all). This scale resembles the one used for grading school work in Hungary (whereby 4 and 5 are regarded as 'good' grades) so as to be easily understood by respondents. Due to the bi-modal distribution of responses (displayed in Fig. 1), a binary dependent variable was employed during the analyses.

Farmers who considered CMs to be important (score 4 or 5) are characterised as CM farmers. A group of farmers who favour FMs was similarly distinguished. Aggregating the top two scores instead of using the top score was done arbitrarily; the decision was made in order to obtain a similar 
Table 3 Descriptive statistics

\begin{tabular}{|c|c|c|c|c|c|}
\hline Variable & $\mathrm{N}$ & Avg & SD & Min & Max \\
\hline \multicolumn{6}{|l|}{ Dependent variables } \\
\hline Preferring conventional markets & 156 & $0.67^{\mathrm{a}}$ & 0.47 & 0 & 1 \\
\hline Preferring farmers' markets & 156 & $0.28^{\mathrm{a}}$ & 0.45 & 0 & 1 \\
\hline \multicolumn{6}{|l|}{ Independent variables } \\
\hline \multicolumn{6}{|l|}{ a. Market-related asset-specificity } \\
\hline $\begin{array}{l}\text { Long-term contract with the } \\
\text { market }\end{array}$ & 153 & 0.69 & 0.47 & 0 & 1 \\
\hline Proportion of regular customers & 143 & 58.78 & 23.09 & 0 & 100 \\
\hline Attends multiple markets & 152 & 0.49 & 0.50 & 0 & 1 \\
\hline \multicolumn{6}{|l|}{ b. Farmer-specific characteristics } \\
\hline Age (years) & 156 & 53.87 & 14.29 & 26 & 85 \\
\hline Secondary education & 156 & 0.481 & 0.501 & 0 & 1 \\
\hline Tertiary education & 156 & 0.237 & 0.427 & 0 & 1 \\
\hline Farming experience (years) & 155 & 21.05 & 16.25 & 0 & 65 \\
\hline \multicolumn{6}{|c|}{ c. Openness and nature of future expectations } \\
\hline Informal cooperation & 154 & 0.21 & 0.41 & 0 & 1 \\
\hline $\begin{array}{l}\text { Plans to invest in farm infra- } \\
\text { structure }\end{array}$ & 156 & 0.37 & 0.48 & 0 & 1 \\
\hline \multicolumn{6}{|l|}{ d. Motivation } \\
\hline Direct selling is preferred & 155 & 0.19 & 0.40 & 0 & 1 \\
\hline Prompt payment & 156 & 0.10 & 0.30 & 0 & 1 \\
\hline \multicolumn{6}{|c|}{ e. Farm and production-specific characteristics } \\
\hline Area (ha.) & 151 & 12.88 & 45.98 & 0 & 367 \\
\hline Number of products & 152 & 21.94 & 33.84 & 1 & 350 \\
\hline
\end{tabular}

${ }^{\mathrm{a}} 18$ producers often sell at both types of market, thus they are classified into both farmer groups. Accordingly, the categories "Preferring conventional markets" and "Preferring farmers' markets" are not additive (figures for CM farmers and FM farmers do not add up to $100 \%)$

scheme to that used to award school grades. This method was used to distinguish the dominant marketing channel (or marketing channels).

To analyse the differences between the groups of farmers (i.e. to test whether average values were the same for the $\mathrm{CM}$ and FM farmers), non-parametric Kruskal-Wallis tests were employed. The variables used in the analyses were then classified into five groups (Table 3 ).

The first group (a) includes variables that were used to test $\mathrm{H} 1$ (the role of transaction costs): the farmer's proportion of regular customers (for the respondent's reportedly most important outlet); whether the respondent has a longterm contract with a market (the characteristics of these contracts are described above); and whether the respondent regularly attends more than one market.

The second group (b) was used to test hypotheses H2a and $\mathrm{H} 2 \mathrm{~b}$. This group consists of farmer-related characteristics such as age, education (measured with dummy variables: $D_{\text {secondary }}=1$ in case of completed secondary education, 0 otherwise; $D_{\text {tertiary }}=1$ in case of completed higher education, 0 otherwise), years of farming experience, etc.

The third group (c) consists of variables that were used to analyse willingness to cooperate and the investment plans of farmers (hypothesis H3). The first is characterized by involvement in informal cooperation (this describes the personal relationships among farmers that facilitate exchanges of work, machinery, etc.) The other variable describes whether the respondent plans to invest in farm infrastructure in the next 3 years. (Details about specific examples of investment plans involving the total amount of money, source, etc. were collected to ensure that real plans were being reported rather than wishes).

Motivation-related variables (hypotheses $\mathrm{H} 4 \mathrm{a}$ and $\mathrm{H} 4 \mathrm{~b}$ ) belong to the fourth group (d). An open-ended question was used to collect data about the reasons for the use of the most important marketing channel (or the mostoften-visited market) and answers were then classified. Two kinds of motivation were considered in the research: whether direct selling was preferred as a means of avoiding longer supply chains (with a view to increasing profits) and whether prompt payment in cash on the spot was considered important.

Variables in the fifth group (e) were used to test hypothesis H5a (farm size) and H5b (farm diversification). Area (expressed in hectares) and the number of products were used as proxies. (The number of products was assessed in a way as to reflect consumer choices and considerations: different varieties of the same species or processed products that contained different species alongside a basic ingredient were regarded as being different).

\section{The dependent variable and discrete choice models}

As farmers' preferences are not mutually exclusive (i.e. farmers may consider both CMs and FMs to be equally important outlets), two independent models were estimated, one for each market type. To identify the factors that influence farmers' preferences for selling at a specific type of market, discrete choice models were used. In the first (CM-) model, the dependent variable was assigned a value of 1 if the conventional form of market was reported to be important to the farmer (importance of ' 4 ' or ' 5 '), otherwise the value assigned was 0 (importance of $0-3$ ). The dependent variable was defined in the same way in the second (FM-) model.

In order to examine the relationships between markets and explanatory variables various binary models were estimated. In principle, both nominal outcome (multinomial logit) and ordered outcome models (ordered logit or probit models) could be used with the aforementioned ordered 
discrete choice dependent variables. However, as Fig. 1 demonstrates, the dependent variables are highly bi-modal; some options involve only 1 or 2 observations so the use of nominal outcome models would be inappropriate. Ordered choice models are based on parallel regressions assumptions (Long and Freese 2014, pp. 326-331).

The methods described above are typically estimated using maximum likelihood after imposing distributional assumptions about error terms. However, the literature about semiparametric models emphasises that parametric estimators of discrete choice models are known to be sensitive to departures from distributional assumptions. Various estimators have been developed to correct this restrictive element of parametric models, including the semi-nonparametric approach of Gallant and Nychka (1987) and the semiparametric maximum likelihood approach of Klein and Spady (1993). The recent literature emphasises that, though computationally more complex, semi-nonparametric and semiparametric maximum likelihood estimators substantially outperform the parametric probit maximum likelihood estimator (De Luca 2008). Accordingly, for the research described in this paper a semi-nonparametric approach was employed. Possible problems caused by heteroscedasticity were avoided by the use of robust variance estimation.

\section{Results}

Altogether, 20 conventional, organic and farmers' markets were visited (Table 7 in the "Appendix"). The total number of respondents was 156 .

\section{The characteristics of small-scale farmer respondents}

The dominance of farmers involved in horticulture (77\%) is an outstanding feature of the sample; the share of animal husbandry farmers is $17 \%$, while mixed farm farmers constitute the rest of the sample (6\%). 33 farmers use organic methods of cultivation of whom 21 are officially certified. 14 organic and 10 non-organic farmers consider CMs and FMs to be unimportant (in other words, they prefer outlets such as OMs, specialized shops, wholesalers, etc.) and were thus excluded from the pairwise comparisons. Conventional markets are considered important by 105 farmers, while 45 farmers reported that FMs were important to them. There is an overlap between CM and FM farmers as 18 farmers sell at both types of market and were thus classified into both groups. This has no effect on the independent discrete choice models and their inclusion or exclusion in the pairwise comparison modifies qualitative findings to only a minor extent (explained below). Descriptive statistics for key variables in the full sample are provided in Table 3.
Sixty-nine percent of farmers have long-term contracts with a market ${ }^{5}$ while $49 \%$ of farmers reported that they regularly visited more than one market. The number of marketing channels was on average 2.4 but the exact number widely varies (up to 11 in the case of an organic farmer who prefers to make sales on-farm and via the internet).

Farmers are found to be typically of middle age. Almost half of them have completed secondary education, further $24 \%$ have completed higher education. Cooperation is very unpopular, even in an informal form: $21 \%$ of farmers are engaged in informal professional relationships. $37 \%$ of farmers have well-defined investment plans for the next 3 years which might be explained by their many years of farming experience ( 21 years on average) which indicates that many of the required investments have already been made.

Regarding motivations, $19 \%$ of respondents mentioned the importance of to increasing profits through direct selling. In addition, during the interviews farmers were asked to estimate the price premium of their chosen market (or one of their preferred markets if they indicated more than one) compared to wholesale markets. The average answer was $29 \%$, which implies that economic considerations must play a role in the decision making of farmers. Avoiding extended periods of payment was not reported to be a main driver of participation.

Farm size is small, at around 13 hectares on average. Four farmers in the sample operate on more than 60 hectares; they are all involved in animal husbandry or run mixed farms. ${ }^{6}$ Bigger (certified) organic farmers predictably offered a greater number of products for sale. (Significant numbers of products were recorded as some farmers use a wide variety of ingredients in their jams, cheeses, etc. to meet diverse consumer demand for exciting premium products. The actual number of cultivars is generally far fewer). These 'big', certified organic farmers do not sell at CMs and FMs, thus they are not included in the pairwise comparisons. Their effect on the results of the discrete choice models is appraised by means of robustness analyses (described below).

\section{What identifies farmers who prefer different types of market?}

To study the differences between the subsamples (CM farmers and FM farmers), non-parametric Kruskal-Wallis tests were employed. The 24 farmers who mostly use different

\footnotetext{
${ }^{5}$ Regarding all the three cities involved in the study, $58 \%$ of the surveys were completed at $\mathrm{CMs}$ where such contracts are typically in use. The difference is due to those farmers who consider both CMs and FMs to be important.

6 The two outlier cases (farmers who farm more than 350 hectares) involve certified organic farmers who do not visit other types of market so they are not involved in the pairwise comparisons.
} 
Table 4 Profiles of farmers who prefer different types of market

\begin{tabular}{lccl}
\hline Variable & CM & FM & $\begin{array}{l}\text { Kruskal- } \\
\text { Wallis test (p } \\
\text { value) }\end{array}$ \\
\hline $\mathrm{N}$ & 105 & 45 & - \\
a. Characteristics of logistics and marketing & & \\
Long-term contract with a market & 0.865 & $0.409^{\mathrm{a}}$ & 0.0001 \\
Proportion of regular customers & 56.426 & 59.186 & 0.5077 \\
Attends multiple markets & 0.410 & 0.911 & 0.0001 \\
b. Farmer-specific characteristics & & & \\
Age (years) & 57.7 & 48.9 & 0.0001 \\
Secondary education & 0.514 & 0.114 & 0.8539 \\
Tertiary education & 0.533 & 0.333 & 0.0316 \\
Farming experience (years) & 25.4 & 14.2 & 0.0001 \\
c. Openness and nature of future expectations & & \\
Informal cooperation & 0.147 & 0.289 & 0.1910 \\
Plans to invest in farm infrastruc- & 0.240 & 0.711 & 0.0001 \\
$\quad$ ture & & & \\
d. Motivation & & & \\
Direct selling is preferred & 0.135 & 0.378 & 0.0166 \\
Prompt payment & 0.096 & 0.022 & 0.4676 \\
e. Farm and production-specific characteristics & & \\
Area (ha.) & 7.649 & 28.000 & 0.0415 \\
Number of products & 15.97 & 24.698 & 0.0031 \\
\hline
\end{tabular}

$C M$ conventional market is important, $F M$ farmers' market is important. Farmers who sell at both markets are included in both groups

${ }^{\text {a }}$ Typically, those FM farmers who also sell at CMs have a contract

marketing channels other than CMs or FMs were excluded from the pairwise comparisons.

Table 4 shows the differences between the two farmers' groups when the 18 farmers who consider both markets equally important are involved (in both groups). Their inclusion decreases the differences between the averages of the groups. ${ }^{7}$

At the $10 \%$ significance level the difference between the groups is significant for most variables. Conventional market farmers are significantly more likely to have signed longterm contracts with their chosen markets (86.5\%), presumably to ensure they benefit from reduced prices. However, this ties them to their markets: $41 \%$ of them reported that they were looking for alternative sales outlets (other markets) where they might sell excess produce or were considering trying another market where consumer demand might be higher-compared to the $91.1 \%$ of FMs who are much more

\footnotetext{
7 To analyse the robustness of the findings, the 18 mixed marketattending farmers were excluded and those factors were re-examined for which no difference was experienced at the 5\% significance level. Only "informal cooperation" proved to be of significance $(\mathrm{p}=0.0446)$, with $12.9 \%$ of CM farmers and $29.6 \%$ of FM farmers favouring informal partnerships, on average.
}

flexible in this regard. CM farmers are typically older and less educated (less of them have completed higher education among them) but they have more farming experience. Although FM farmers have 14 years of experience on average (which might be considered long enough for them to develop their farms), significantly more of them (71\%) have investment plans for the next 3 years. FM farmers seem to be more motivated by the potential profit to be gained via direct sales than CM farmers.

The area that CM farmers farm is much smaller (the average $\mathrm{CM}$ farmer farms 8 hectares) than the average area used by FM farmers. As a consequence, product diversity is much lower.

When farmers who regularly visit both markets are disregarded, the higher willingness of FM farmers to enrol in informal partnerships is confirmed. It may be stated in summary that the two groups of farmers differ to a significant extent in terms of their characteristics.

\section{Factors that influence the preference for a specific market type}

For this section of the research, two model arrangements were considered: First, the factors influencing the preference for CMs were analysed, while the second group of models focused on FMs.

Certified organic farmers differ from non-organic ones in many respects. (For a comparison of certified organic farmers and the rest of the sample see Table 8 in the "Appendix".) Though technically they could attend any type of market, some of them never do. Accordingly, the sample of certified organic farmers was split: the 14 farmers who do not consider CMs or FMs to be important were excluded, and the 7 certified organic farmers who visit non-organic markets were incorporated into the analysis. (These 7 farmers are more similar to non-organic farmers in terms of farm scale: the largest of their farms is 46 hectares in size while the others have less than 15 ha. each.). Variables which influence the importance awarded to different types of market are displayed in Table 5.

The sample size was reduced to 116 in the $\mathrm{CM}$, and to 114 in the FM models; these numbers include respondents who replied to all the questions.

In the $\mathrm{CM}$ model, 9 out of the 13 variables prove to be significant (all but one of at a level of $1 \%$ ). The positive effects of long-term contracts in establishing commitment towards a market are confirmed: those who have such contracts are more likely to prefer CMs (H1a). This outcome is supported by another finding that concerns multiple markets: farmers who visit several markets (i.e. are less committed to a single one) are less likely to prefer CMs. In contrast to expectations ( $\mathrm{H} 1 \mathrm{~b})$, farmers having higher share of regular customers is found to prefer CMs less. Older and less 
Table 5 Factors influencing the importance placed on different types of market (excluding certified organic farmers who attach no importance to $\mathrm{CMs}$ or FMs)

\begin{tabular}{|c|c|c|}
\hline Variable & $\begin{array}{l}\text { Preferring conventional } \\
\text { markets }\end{array}$ & $\begin{array}{l}\text { Preferring } \\
\text { farmers' } \\
\text { markets }\end{array}$ \\
\hline \multicolumn{3}{|l|}{ a. Characteristics of logistics and marketing } \\
\hline Long-term contract with the market & $2.880 * * *$ & $-4.618 * * *$ \\
\hline Proportion of regular customers & $-0.016^{* * *}$ & $0.031 * * *$ \\
\hline Attends multiple markets & $-1.309 * * *$ & $6.401 * * *$ \\
\hline \multicolumn{3}{|l|}{ b. Farmer-specific characteristics } \\
\hline Age (years) & $0.020 * * *$ & $-0.049 * *$ \\
\hline Secondary education & 0.267 & $-1.021 * * *$ \\
\hline Tertiary education & $-1.539 * * *$ & $0.723^{*}$ \\
\hline Farming experience (years) & -0.013 & 0.004 \\
\hline \multicolumn{3}{|c|}{ c. Openness and nature of future expectations } \\
\hline Informal cooperation & 0.024 & -0.602 \\
\hline Plans to invest in farm infrastructure & $-1.410^{* * *}$ & $2.269 * * *$ \\
\hline \multicolumn{3}{|l|}{ d. Motivation } \\
\hline Direct selling is preferred & $-0.504^{*}$ & $3.325 * * *$ \\
\hline Prompt payment & $2.111 * * *$ & $-2.466^{* * *}$ \\
\hline \multicolumn{3}{|c|}{ e. Farm and production-specific characteristics } \\
\hline Area (ha.) & $-0.032 * * *$ & $0.055 * * *$ \\
\hline Number of products & -0.011 & $0.095 * * *$ \\
\hline $\mathrm{N}$ & 116 & 114 \\
\hline Log pseudolikelihood & -33.278 & -9.823 \\
\hline Log likelihood ratio test & 0.006 & 0.015 \\
\hline Wald test (p value) & 0 & 0 \\
\hline
\end{tabular}

Out of the subsample described in the text, 116 and 114 respondents replied to all the questions concerning the CM and FM model, respectively

$* p<0.1$

$* * p<0.5$

$* * * p<0.01$

educated ${ }^{8}$ farmers are more likely to find CMs to be important outlets for their products ( $\mathrm{H} 2 \mathrm{a}$ and $\mathrm{b})$. The effect of experience in itself could not be confirmed. Participation in informal partnerships has no effect on the preference for CMs (H3a). Bigger Hungarian enterprises which operate on a larger area, or which are likely to invest in their farms in the next 3 years are less likely to find CMs important, thus hypotheses $\mathrm{H} 5 \mathrm{a}$ and $\mathrm{H} 3 \mathrm{~b}$ are confirmed, while no evidence is found for the role of the number of products offered for sale in preference for market type (H5b). In terms of motivation, those who prefers direct selling seem to place on CMs less importance (and choose for example FMs instead, see below), so hypothesis $\mathrm{H} 4 \mathrm{a}$ with respect to CMs could not be confirmed. Prompt payment is found to be an important source of motivation $(\mathrm{H} 4 \mathrm{~b})$.

In the case of the FM-model, there are 11 significant variables. The hypothesis that long-term contracts (and commitment

\footnotetext{
${ }^{8}$ Having completed higher education seem to have a negative effect on the preference for $\mathrm{CMs}$, while the effect of secondary education itself is not significant.
}

to a single market) is regarded as more of a constraint than an opportunity by FM farmers (H1a) is confirmed. Having regular customers has a positive effect on the evaluation of FMs (H1b is confirmed). In line with expectations (H2a), older farmers are less likely to find FMs important outlets. Similarly to the $\mathrm{CM}$ models, experience seems to have no effect on its own. The level of education matters in the preference for FMs: those who have secondary education are less likely to find FMs important, while having completed higher education seems to have positive effect (H2b confirmed). Having informal partnerships do not seem to have a significant effect (H3a). Farmers with future plans in terms of investments are more likely to be partial to FMs; thus hypothesis $\mathrm{H} 3 \mathrm{~b}$ (which posits a connection between openness and FM participation) is confirmed. The potential for making more profit from direct sales was found to be a motivating factor for FM-centric farmers ( $\mathrm{H} 4 \mathrm{a}$ ). FM farmers, who can be characterized by their bigger and more diverse farms (see Table 4), seem to be affected by these factors, as such farm- and production-related characteristics appear to positively impact the probability that farmers will prefer FMs (H5a and H5b are thus confirmed). 
Table 6 Factors influencing the reported importance of different types of market (full sample)

\begin{tabular}{lll}
\hline Variable & CM-model & FM-model \\
\hline a. Characteristics of logistics and marketing & & \\
Long-term contract with the market & $1.885^{* * *}$ & $-1.976^{* * *}$ \\
Proportion of regular customers & $-0.016^{* *}$ & $-\mathbf{0 . 0 0 5}$ \\
Attends multiple markets & $-0.753^{* * *}$ & $2.971^{* * *}$ \\
b. Farmer-specific characteristics & & \\
Age (years) & $\mathbf{0 . 0 0 6}$ & $\mathbf{0 . 0 3 9 * * *}$ \\
Secondary education & -0.250 & $\mathbf{0 . 3 3 4}$ \\
Tertiary education & $-0.936^{* *}$ & $0.892^{*}$ \\
Farming experience (years) & 0.024 & -0.019 \\
c. Openness and nature of future expectations & \\
Informal cooperation & 0.024 & $\mathbf{1 . 4 3 9 * * *}$ \\
Plans to invest in farm infrastructure & $\mathbf{- 0 . 4 9 1}$ & $2.275^{* * *}$ \\
d. Motivation & & \\
Direct selling is preferred & $\mathbf{- 0 . 4 4 2}$ & $1.307^{* * *}$ \\
Prompt payment & $\mathbf{- 0 . 0 0 7}$ & $-2.229^{* * *}$ \\
e. Farm and production-specific characteristics & \\
Area (ha.) & $\mathbf{- 0 . 0 0 7}$ & $\mathbf{0 . 0 0 1}$ \\
Number of products & $\mathbf{- 0 . 0 1 6 *}$ & $-\mathbf{0 . 0 2 9} * * *$ \\
N & 129 & 129 \\
Log pseudolikelihood & -41.623 & -26.821 \\
Log likelihood ratio test & 0.035 & 0.073 \\
Wald test (p value) & 0 & 0 \\
\hline
\end{tabular}

Answers from 129 respondents who provided responses to all the questions were included. Variables where significance has changed compared to Table 5 are indicated in bold, while variables for which the sign changes are shown in bold and italics

${ }^{*} p<0.1$

$* * p<0.5$

$* * * p<0.01$

The discrete choice models described above are related to a sub-sample which excluded certified organic farmers who consider CMs and FMs to be unimportant. To understand the extent to which the effects experienced might be influenced by the inclusion of these organic farmers (on the basis that, in principle, they can freely choose to visit other types of market), a robustness analysis was carried out: the analysis was repeated with the full sample (Table 6).

In the case of the CM-model, the effect of the inclusion of organic farmers is clearly visible. Signs do not change, but less variables prove to be significant in the extended model: age, investment plans, motivations related to direct selling or prompt payment and area size seem to have no effect on preferences; while (in line with previous expectations, H5b) farmers selling higher number of products are less likely to find CMs as important outlets. Variables of which significance does not change, thus they can be regarded as generally important, include commitments towards the market (being stronger in terms of having long-term contracts or visiting a single market only results in higher level of preference; H1a); tertiary education (which makes finding CMs important less likely, H2b). Also, the negative sign for the proportion of regular customers is stable, which is counterintuitive $(\mathrm{H} 1 \mathrm{~b})$.

Results with respect to FMs are less stable in a sense that signs change in two (unexpected) cases. In the extended model age seem to have a positive, while farm diversification a negative impact on placing importance on FMs. The significance of four further variables is variable: the proportion of regular customers, the effect of secondary education, and the area farmed, do not prove to be robust, while being involved in any informal cooperation makes the preference for FMs more probable. The effect of the rest of the seven variables seems to be stable.

\section{Discussion}

Our results harmonize with the literature in many respects. We confirmed the results of Brown (2002), Juhász (2012), Kneafsey et al. (2013) and others that market farmers in general are typically in their middle ages who prefer to get along alone instead of cooperating with others (see e.g. Bakucs et al. 2012). Small area cultivated is also considered to be typical in case of farmers participating in SFSCs (Lass et al. 2003; Meert et al. 2005; Juhász 2012).

The use of a more conventional marketing channel is typical for those who are older, less educated (see Juhász 2012; Kneafsey et al. 2013 and others) and operate at an even smaller scale (Lass et al. 2003; Jarosz 2008; Kneafsey et al. 2013).

With respect to motivations, the finding of this research (i.e. the low reporting of direct selling in the whole sample) is in contrast to that of Bakucs et al. (2012), Fertô et al. (2011) and Juhász (2012) who stress the direct and utmost importance of economic considerations in the choice of marketing channels. It is possible that the experienced difference is the result of social desirability biases (Grimm 2010): farmers preferred not to speak openly about their financial status and monetary expectations but rather stressed more 'respectable' reasons for participating, such as enjoying the good atmosphere of the market or the role of personal narratives in their decisions. On the other hand, the positive effect of this factor has been confirmed in the FM-model, in line with Kirwan (2006) and Kneafsey et al. (2013). The importance of prompt payment as a motivating factor could be confirmed (in line with Cungu et al. 2008; Bakucs et al. 2012) only in case of those non-organic farmers who find CMs important; the negative sign in the FM-model is contra intuitive.

The novelty of this analysis is two-fold. From a theoretical point of view, it demonstrates that farmers' markets and conventional markets are two different governance mechanisms. Technically, as CMs are characterized by contracting, 
farmers' sales in CMs help preventing transaction-related problems. However, in reality, the great advantage of the newly-emerged FMs seems to be, besides the higher profit that can be realized, the lack of rigorous and binding contracts. This freedom allows farmers, who are open and flexible, to visit multiple markets; thus an opportunity for a trial and error strategy in terms of finding the best outlet is provided. There are additional differences between the two types of market based on further characteristics offered by the TCE literature. Out of these characteristics, the ones that are related to the identity of the partners (irrelevance of identity, ex ante restriction on the choice of the partner) are of particular interest. While the rest of the variables clearly imply that FMs can be considered as examples of spot markets, and CMs are more vertically integrated (being based on noncontractual relationships, see Gellynck and Molnár 2009), these partner-focused variables call for a subtle distinction.

Regarding practical aspects, the paper shows that there are two major groups of market-oriented non-organic smallscale farmers who prefer different types of market. The mixed use of the typical types of market is less common. Different factors that are related to socio-economic status, production methods and the use of marketing channels have a contrasting impact on the appreciation of the different types of market. The existence of different types of farmers-and their characteristics—should be acknowledged during policy-making, especially in the light of the new SFSCs-focused efforts of the $\mathrm{EU}$, to ensure the greater efficiency of policy implementation by tailoring specific, targeted frameworks and interventions to the needs of the different types of farmers.

\section{Conclusions and implications}

Alternative food systems are gaining more and more importance worldwide. With regard to the rapid and profound changes taking place in the Hungarian agri-food sector, the aim of the research described in this paper is to analyse the factors that have an impact on a farmer's evaluation of specific SFSCs. Special attention is paid to the different types of market (conventional markets, CMs, and newly emerging, 'western type' farmers' markets, FMs) that are present in the bigger Hungarian cities and other areas of greater purchasing power.

The key findings of the research are the following: CMs and FMs are two different types of market with respect to governance mechanisms; FMs can be regarded as examples (though not clear examples) of spot markets, while CMs are closer to vertical integration. The newly-introduced FMs are becoming viable and complementary points of sale for farmers; they are required to co-exist with CMs that are deeply embedded in the socio-cultural context in transition countries, as they provide several advantages such as higher prices, or the lack of binding contracts. Consequently, from both theoretical and practical points of view, the different types of market should not be regarded as a single, homogeneous governance structure.

Our research highlights that farmers' profiles are considerably different according to the type of market they prefer. Less educated and less future-oriented small-scale farmers are mostly interested in selling at CMs. As these farmers are typically committed to their chosen markets and rarely use the new opportunities offered them by FMs, they seem to be most in need of further assistance (education, an organisational body, etc.). Such assistance could promote their effective participation in the growing local food movement and help them to obtain better prices for their goods-if they are also able to produce the high-quality products that consumers demand. The use of FMs is a part of the risk-sharing and diversification strategy of farmers who participate. Education, investment plans, a preference for direct selling (rather than being involved in longer supply chains) and no commitment to a single market seem to be important in a positive evaluation of FMs. In addition, based on farmers' perceptions, FMs can also help raise the incomes of farmers through their potential for increasing profits.

The paper has several practical implications. The differences between the markets and the farmers who participate in them should be taken into account when support for small-scale farmers and alternative food systems is considered during the planning of rural or social development policies and programmes. There is a need for a more targeted approach to ensure the participation of small-scale farmers in alternative food systems. As it has been revealed, almost $60 \%$ of the farmers who visit CMs attend a single market; supporting them with a 'simple' monetary scheme (such as direct support) would perhaps prove ineffective. In other words, as many CM farmers are not responsive to the potentially pre-existing monetary incentive offered by FMs and other marketing channels, non-monetary incentive structures (such as experience exchange programs, consultancy networks that could provide guidance about marketing and better regulation of contracts, etc.) should be also considered as support and development tools for promoting SFSCs.

Further, from the practical point of view of conventional market managers, the role and the specifics of the contracts should be revisited. A less controlled farmer-CM relationship might be more appealing for a bigger group of smallscale farmers, which might increase the variety of products (since farmers nowadays preferring FMs offer a higher selections of goods), which could increase the overall attraction of the market. Farmers could also benefit from a lower level of control; either by not paying in case of their absence or by visiting other points of sale.

Our study raises a number of opportunities for future research. For example, further classification development related to the determining variables could improve the 
understanding about the exact location of CMs and FMs on the vertical coordination continuum. Moreover, further research is needed in order to fully support public policy formulation and implementation. Questions could include (but not be limited to) the following: Is the launch of the EU SFSC Thematic Sub-programme enough to improve the competitiveness of small-scale farmers, and how to measure its success? Given the local character of SFSCs, what can be the role of sub-national and sub-regional authorities? How to ensure the traceability of local food and the compliance with food safety legislation? This latter aspect is particularly important in order to increase the overall social acceptance of local food.

The main limitation of the research described herein is its representativeness. There are no national or regional statistics about markets within the direct sales sector in Hungary so the findings contained herein cannot be compared with any prior expectations or current analyses. Furthermore, the number of FMs is still growing and the importance of other marketing channels is also increasing, so further changes may be anticipated.

Acknowledgements The assistance of Lajos Baráth and József Tóth with data collection is highly appreciated. Ágnes Major provided comments on the section containing the systematic comparison of conventional and farmers' markets. The authors are grateful to Andrew Fieldsend and Simon Milton for their language-related contributions. Zsófia Benedek was supported by the Hungarian Scientific Research Fund under Grant OTKA PD 109177. Adrienn Molnár acknowledges the financial support of the Hungarian Scientific Research Fund (OTKA, PD 116226) 'Supply chain and network performance and relationships in the agribusiness sector'.

\section{Compliance with ethical standards}

Ethical approval All procedures performed in studies involving human participants were in accordance with the ethical standards of the institutional and/or national research committee and with the 1964 Helsinki declaration and its later amendments or comparable ethical standards.

Open Access This article is distributed under the terms of the Creative Commons Attribution 4.0 International License (http://creativeco mmons.org/licenses/by/4.0/), which permits unrestricted use, distribution, and reproduction in any medium, provided you give appropriate credit to the original author(s) and the source, provide a link to the Creative Commons license, and indicate if changes were made.

\section{Appendix}

See Tables 7 and 8 .

Table 7 Markets visited, main characteristics

\begin{tabular}{|c|c|c|c|c|c|c|}
\hline$\overline{\text { City }}$ & Name (location) & Type & Market days/week & Size $^{a}$ & Opening date & $\begin{array}{l}\text { Number of farmers in } \\
\text { the final sample }\end{array}$ \\
\hline \multirow[t]{12}{*}{ Budapest } & Csepel market hall & $\mathrm{CM}$ & 6 (Mon-Sat) & Large & Before 1989 & 6 \\
\hline & Hunyadi square market hall & $\mathrm{CM}$ & 6 (Mon-Sat) & Large & Before 1989 & 5 \\
\hline & Lehel square market hall & $\mathrm{CM}$ & 6 (Mon-Sat) & Large & Before 1989 & 13 \\
\hline & Újpest market hall & $\mathrm{CM}$ & 6 (Mon-Sat) & Large & Before 1989 & $19^{c}$ \\
\hline & Kelenvölgy farmers' market & FM & $1(\mathrm{Thu})$ & Micro & 2011 & 1 \\
\hline & Erzsébetváros farmers' market & FM & 1 (Sat) & Small & 2012 & 4 \\
\hline & Gazdagrét farmers' market & FM & 1 (Sat) & Small & 2011 & 9 \\
\hline & Gazdakert market & FM & 2 (Wed, Sat) & Small & 2013 & 3 \\
\hline & Szimpla Kert farmers' market & FM & 1 (Sun) & Medium & 2012 & 9 \\
\hline & Virágpiac (Szent László road) & FM & 1 (Sun) & Medium & 2012 & 4 \\
\hline & SZÖVET farmers' market (Csaba street) & FM & 2 (Wed, Sat) & Small $^{\mathrm{b}}$ & 2013 & 1 \\
\hline & MOM organic market & $\mathrm{OM}$ & 1 (Sat) & Large & 1999 & 9 \\
\hline \multirow[t]{7}{*}{ Debrecen } & Angyalföld Square small market & $\mathrm{CM}$ & 6 (Mon-Sat) & Micro & Before 1989 & 3 \\
\hline & Fényes Court small market & $\mathrm{CM}$ & 6 (Mon-Sat) & Micro & Before 1989 & 1 \\
\hline & Malompark small market & $\mathrm{CM}$ & 6 (Mon-Sat) & Small & 1998 & 3 \\
\hline & Grand market & $\mathrm{CM}$ & 6 (Mon-Sat) & Large & Before 1989 & 7 \\
\hline & Ifjúsági ház market & FM & $1(\mathrm{Thu})$ & Micro & 2013 & 3 \\
\hline & Homokkert market & FM & $1(\mathrm{Thu})$ & Small & 2013 & 7 \\
\hline & Bioudvar market (Kandia street) & $\mathrm{OM}$ & 1 (Sat) & Small & 2009 & 4 \\
\hline Tura & Food market & $\mathrm{CM}$ & 3 (Tue, Thu, Sat) & Large & Before 1989 & $18^{\mathrm{c}}$ \\
\hline Total number & - & - & - & - & - & 129 \\
\hline
\end{tabular}

$C M$ conventional market, $F M$ farmers' market, $O M$ organic market

${ }^{a}$ Micro: 5-8 vendors; Small: 9-30 vendors; Medium: 31-55 vendors; Large: > 56 vendors (based on Stephenson et al. 2008)

${ }^{\mathrm{b}}$ This market is based on farmers' collaborative efforts. Only 4-5 vendors sell at one time but they collect together products from several families

${ }^{c}$ Farmers were interviewed on different days of the week in order to ensure broad representation (farmers typically attend markets $1-3$ days per week) 
Table 8 Comparison of certified organic farmers with the rest of the sample

\begin{tabular}{|c|c|c|c|}
\hline Variable & $\begin{array}{l}\text { Certified organic } \\
\text { farmers }\end{array}$ & Rest of the sample & $\begin{array}{l}\text { Kruskal-Wal- } \\
\text { lis test (p } \\
\text { value) }\end{array}$ \\
\hline $\mathrm{N}$ & 21 & 135 & - \\
\hline \multicolumn{4}{|l|}{ Characteristics of logistics and marketing } \\
\hline Long-term contract with the market & 0.40 & 0.73 & 0.0177 \\
\hline Proportion of regular customers & 61.86 & 58.25 & 0.0431 \\
\hline Attends multiple markets & 0.53 & 0.48 & 0.7525 \\
\hline \multicolumn{4}{|l|}{ Farmer-specific characteristics } \\
\hline Age (years) & 48.48 & 54.70 & 0.0513 \\
\hline Secondary education & 0.52 & 0.47 & 0.7156 \\
\hline Tertiary education & 0.48 & 0.20 & 0.0419 \\
\hline Farming experience (years) & 12.33 & 22.41 & 0.0092 \\
\hline \multicolumn{4}{|l|}{ Openness and nature of future expectations } \\
\hline Informal cooperation & 0.24 & 0.20 & 0.7976 \\
\hline Plans to invest in farm infrastructure & 0.47 & 0.35 & 0.3462 \\
\hline \multicolumn{4}{|l|}{ Motivation } \\
\hline Direct selling is preferred & 0.35 & 0.17 & 0.1951 \\
\hline Prompt payment & 0.19 & 0.08 & 0.4215 \\
\hline \multicolumn{4}{|c|}{ Farm- and production-specific characteristics } \\
\hline Area (ha.) & 44.31 & 7.81 & 0.0061 \\
\hline Number of products & 60.29 & 15.80 & 0.0000 \\
\hline
\end{tabular}

\section{References}

Alber, J., and U. Kohler. 2008. Informal food production in the enlarged European Union. Social Indicators Research 89: 113-127.

Aubert, M. 2015. The determinants of selling through a short food supply chains: an application to the French case. 9. Journ ees de recherches en sciences sociales (JRSS), Dec 2015, Nancy, France. Actes des journ ees JRSS 2015, p. 25.

Bakacsi, G., T. Sándor, K. András, and I. Viktor. 2002. Eastern European cluster: tradition and transition. Journal of World Business 37: 69-80.

Bakucs, L. Z., I. Fertő, and G. Szabó. 2012. Benefits of a Marketing Co-operative in a transition agriculture: Mórakert Purchasing and Service Co-operative. Society and Economy 34: 453-468.

Balázs, B. 2012. Local food system development in Hungary. International Journal of Sociology of Agriculture and Food 19: 403-421.

Benedek, Z., I. Fertő, L. Baráth, and J. Tóth. 2014. Factors Influencing the Decision of Small-scale Farmers on Marketing Channel Choice: a Hungarian Case Study. In Factors Influencing the Decision of Small-scale Farmers on Marketing Channel Choice: a Hungarian Case Study. pp. 26-29. Slovenia: Ljubljana.

Blay-Palmer, A., K. Landman, I. Knezevic, and R. Hayhurst. 2013. Constructing resilient, transformative communities through sustainable "food hubs". Local Environment 18: 521-528.

Borec, A., and J. Prišenk. 2013. Models of partnerships and organisational forms in short food supply chains in the Slovenian mountains. Economics of Agriculture 60 (2): 277-286.

Brown, A. 2002. Farmers' market research 1940-2000: an inventory and review. American Journal of Alternative Agriculture 17: $167-176$

Brown, C., and S. Miller. 2008. The impacts of local markets: a review of research on farmers markets and community supported agriculture (CSA). American Journal of Agricultural Economics 90: $1298-1302$.
Burch, D., G. Lawrence, and L. Hattersley. 2013. Watchdogs and ombudsmen: monitoring the abuse of supermarket power. Agriculture and Human Values 30: 259-270.

Carbone, A., and G. Subioli. 2011. The Generation Turnover in Agriculture: The Ageing Dynamics and the EU Support Policies to Young Farmers. In The Common Agricultural Policy After the Fischler Reform: National Implementations, Impact Assessment and the Agenda for Future Reforms, eds. R. Henke, A. Sorrentino, and S. Severini, p. 375. Farnham: Ashgate.

Claro, D. P., G. Hagelaar, and S. W. F. Omta. 2004. How to manage a relationship and be successful: A study of the network and buyer-supplier relationship in the Dutch potted flower and plant industry. Dynamics in Chains and Networks, Wageningen (2004). pp. 203-210.

Csáki, C. and C. Forgács. 2008. Observations on regional level. In Restructuring market relations in food and agriculture in Central and Eastern Europe: impacts upon small farmers, eds. C. Csáki, C. Forgács, D. Milczarek-Andrejewska, and J. Wilkin, pp. 207-250. Budapest: Agroinform.

CSO. 2012. 6.3.1.2. Gross domestic product per capita (2000-). In 6.3.1.2. Gross domestic product per capita (2000-): Central Statistical Office.

Cungu, A., H. Gow, J. F. Swinnen, and L. Vranken. 2008. Investment with weak contract enforcement: evidence from Hungary during transition. European Review of Agricultural Economics 35: 75-91.

Davidova, S., L. Fredriksson, and A. Bailey. 2009. Subsistence and semi-subsistence farming in selected EU new member states. Agricultural Economics 40: 733-744.

De Luca, G. 2008. SNP and SML estimation of univariate and bivariate binary-choice models. Stata Journal 8: 190.

Dries, L., T. Reardon, and J. F. M. Swinnen. 2004. The rapid rise of supermarkets in Central and Eastern Europe: Implications for the agrifood sector and rural development. Development Policy Review 22: 525-556. 
Fertő, I., Z. Bakucs, S. Elek, and C. Forgács. 2011. Contracts in Hungarian Food Chains. In Contracts in Hungarian Food Chains, MIC 2011: Managing Sustainability? Proceedings of the 12th International Conference, Portorož, 23-26 November 2011, 425-436: University of Primorska, Faculty of Management Koper.

Gallant, A. R., and D. W. Nychka. 1987. Semi-nonparametric maximum likelihood estimation. Econometrica: Journal of the Econometric Society 55: 363-390.

Gardner, J. T., M. C. Cooper, and T. Noordewier. 1994. Understanding shipper-carrier and shipper-warehouser relationships: Partnerships revisited. Journal of Business Logistics 15 (2): 121-143.

Gassenheimer, J. B., R. J. Calantone, J. M. Schmitz, and R. A. Robicheaux. 1994. Models of channel maintenance: What is the weaker party to do. Journal of Business Research 30 (3): 225-236.

Gellynck, X., and A. Molnár. 2009. Chain governance structures: the European traditional food sector. British Food Journal 111 (8): $762-775$.

Grimm, P. 2010. Social desirability bias. Hoboken: Wiley International Encyclopedia of Marketing.

Hardesty, S. D., and P. Leff. 2010. Determining marketing costs and returns in alternative marketing channels. Renewable agriculture and food systems 25 (1): 24-34.

Henderson, D. R. 1994. Measuring and Assessing Vertical Ties in the Agro-food System. Canadian Journal of Agricultural Economics 42 (4): 549-560.

Hinrichs, C. C. 2000. Embeddedness and local food systems: notes on two types of direct agricultural market. Journal of rural studies 16 (3): 295-303.

Ilbery, B., D. Watts, S. Simpson, A. Gilg, and J. Little. 2006. Mapping local foods: evidence from two English regions. British Food Journal 108: 213-225.

Jagdev, H. S., and K. D. Thoben. 2001. Anatomy of enterprise collaborations. Production Planning and Control 12 (5): 437-451.

James, H. S., Jr. 2000. Separating contract from governance. Managerial and Decision Economics 21: 47-61.

Jarosz, L. 2008. The city in the country: Growing alternative food networks in Metropolitan areas. Journal of Rural Studies 24: 231-244.

Jehlička, P., and J. Smith. 2011. An unsustainable state: Contrasting food practices and state policies in the Czech Republic. Geoforum 42: 362-372.

Jehlička, P., T. Kostelecký, and J. Smith. 2013. Food Self-Provisioning in Czechia: Beyond Coping Strategy of the Poor: A Response to Alber and Kohler's 'Informal Food Production in the Enlarged European Union'(2008). Social Indicators Research 111: 219-234.

John, G., and B. A. Weitz. 1988. Forward Integration into Distribution: An Empirical Test of Transaction Cost Analysis. Journal of Law, Economics and Organization 4 (2): 337-355.

Juhász, A. 2012. A közvetlen értékesités szerepe és lehetôségei a hazai élelmiszerek piacrajutásában [The current performance and opportunities of farm-direct sales in the food supply chain in Hungary]. Agrárgazdasági Tanulmányok [Agroeconomic Studies]. Budapest: Agrárgazdasági Kutató Intézet [Research Institute of Agricultural Economics].

Juska, A., A. Poviliunas, and R. Pozzuto. 2005. Resisting marginalisation: the rise of the rural community movement in Lithuania. Sociologia Ruralis 45: 3-21.

Kirwan, J. 2006. The interpersonal world of direct marketing: examining conventions of quality at UK farmers' markets. Journal of Rural Studies 22: 301-312.

Klein, R. W., and R. H. Spady. 1993. An efficient semiparametric estimator for binary response models. Econometrica: Journal of the Econometric Society 61: 387-421.

Kneafsey, M., L. Venn, U. Schmutz, B. Balázs, L. Trenchard, T. Eyden-Wood, E. Bos, G. Sutton, and M. Blackett. 2013. Short
Food Supply Chains and Local Food Systems in the EU. A State of Play of their Socio-Economic Characteristics. JRC Scientific and Policy Reports: Joint Research Centre Institute for Prospective Technological Studies, European Commission.

Lang, K. B. 2010. The Changing Face of Community-Supported Agriculture. Culture, Agriculture, Food and Environment 32 (1): $17-26$.

Lass, D., A. Bevis, G. Stevenson, J. Hendrickson, and K. Ruhf. 2003. Community supported agriculture entering the 21st century: Results from the 2001 national survey. Amherst: University of Massachusetts, Department of Resource Economics.

Lawson, R., J. Guthrie, A. Cameron, and W. C. Fischer. 2008. Creating value through cooperation: An investigation of farmers' markets in New Zealand. British Food Journal 110: 11-25.

Long, J. S., and J. Freese. 2014. Regression models for categorical dependent variables using Stata. College Station: Stata Press.

Lu, H., J. H. Trienekens, and S. W. F. Omta. 2006. Does Guanxi Matter for Vegetable Supply Chains in China? A Case Study Approach. 7th International Conference on Management in AgriFood Chains and Networks, Ede, The Netherlands, 31 May - 2 June 2006.

Macneil, I. R. 1978. Contracts: Adjustment of Long Term Relations Under Classical, Neoclassical, and Relational Contract Law. Northwestern University Law Review of Agricultural Economics 72: 854-905.

Martinez, S., M. Hand, M. Da Pra, S. Pollack, K. Ralston, T. Smith, S. Vogel, S. Clark, L. Lohr, S. Low, and C. Newman. 2010. Local Food Systems: Concepts, Impacts, and Issues. ERR. 97. Waonferemshington: U.S. Department of Agriculture, Economic Research Service.

Maye, D., and J. Kirwan. 2010. Alternative food networks. Sociology of Agriculture and Food entry for Sociopedia. isa. http://www. sagepub.net/isa/resources/pdf/Alternative\%20Food\%20Networks .pdf Accessed 09 September 2017.

Meert, H., G. Van Huylenbroeck, T. Vernimmen, M. Bourgeois, and E. Van Hecke. 2005. Farm household survival strategies and diversification on marginal farms. Journal of Rural Studies 21: 81-97.

Mincyte, D. 2011. Subsistence and Sustainability in Post-industrial Europe: The Politics of Small-scale Farming in Europeanising Lithuania. Sociologia Ruralis 51: 101-118.

Möllers, J., G. Buchenrieder, and C. Csáki. 2011. Structural change in agriculture and rural livelihoods: Policy implications for the New Member States of the European Union. Studies on the agricultural and food sector in Central and Eastern Europe. No. 61. Leibniz Institute of Agricultural Development in Transition Economies (IAMO). http://nbn-resolving.de/urn:nbn:de:gbv:3:2-18711. Accessed 09 Sept 2017.

Noordewier, T. G., G. John, and J. R. Nevin. 1990. Performance outcomes of purchasing arrangements in industrial buyer-vendor relationships. Journal of Marketing 54 (4): 80-93.

Omamo, S. W. 1998. Farm-to-market transaction costs and specialisation in small-scale agriculture: Explorations with a non-separable household model. The Journal of Development Studies 35: 152-163.

Ouma, E., J. Jagwe, G. A. Obare, and S. Abele. 2010. Determinants of smallholder farmers' participation in banana markets in Central Africa: the role of transaction costs. Agricultural Economics 41: 111-122.

Peterson, H. C., A. Wysocki, and S. B. Harsh. 2001. Strategic choice along the vertical coordination continuum. International Food and Agribusiness Management Review 4: 149-166.

Raynaud, E., L. Sauvee, and E. Valceschini. 2005. Alignment between quality enforcement devices and governance structures in the agro-food vertical chains. Journal of Management \& Governance 9 (1): 47-77.

Renko, S., M. Cerjak, R. Haas, F. Brunner, and M. Tomić. 2014. What motivates consumers to buy traditional food products? Evidence 
from Croatia and Austria using word association and laddering interviews. British Food Journal 116: 1726-1747.

Renting, H., T. K. Marsden, and J. Banks. 2003. Understanding alternative food networks: exploring the role of short food supply chains in rural development. Environment and planning A 35: 393-412.

Saenger, C., M. Qaim, M. Torero, and A. Viceisza. 2013. Contract farming and smallholder incentives to produce high quality: Experimental evidence from the Vietnamese dairy sector. Agricultural Economics 44: 297-308.

Schulze, B., A. Spiller, and L. Theuvsen. 2006. Is more vertical integration the future of food supply chains? Empirical evidence and theoretical considerations from German pork production. In 7th International Conference on Management in AgriFood Chains and Networks. Wageningen: Wageningen Academic Publishers.

Schweitzer, J., and S. P. Gudergan. 2011. Contractual complexity, governance and organisational form in alliances. International Journal of Strategic Business Alliances 2 (1-2): 26-40.

Sharma, A., and J. N. Sheth. 1997. Relationship marketing: An agenda for inquiry. Industrial Marketing Management 26 (2): 87-89.

Spilková, J., L. Fendrychová, and M. Syrovátková. 2013. Farmers' markets in Prague: a new challenge within the urban shoppingscape. Agriculture and Human Values 30: 179-191.

Sporleder, T. L. 1992. Managerial economics of vertically coordinated agricultural firms. American Journal of Agricultural Economics 74 (5): 1226-1231.

Stephenson, G., L. Lev, and L. Brewer. 2008. 'I'm getting desperate': what we know about farmers' markets that fail. Renewable Agriculture and Food Systems 23: 188-199.

Swinnen, J. F., and M. Maertens. 2007. Globalization, privatization, and vertical coordination in food value chains in developing and transition countries. Agricultural Economics 37: 89-102.

Trent, R. J. 2005. Why RELATIONSHIPS Matter. Supply Chain Management Review 9 (8): 53-60.

Watts, D. C., B. Ilbery, and D. Maye. 2005. Making reconnections in agro-food geography: alternative systems of food provision. Progress in Human Geography 29: 22-40.

Webster, J. F. E. 1992. The changing role of marketing in the corporation. Journal of Marketing 56 (4): 1.

Williamson, O. E. 1973. Markets and hierarchies: some elementary considerations. American Economic Review 63: 316-325.

Williamson, O. E. 1979. Transaction-Cost Economics: The Governance of Contractual Relations. Journal of Law and Economics 22 (2): 233-261.
Zsófia Benedek is a Research Fellow at the Institute of Economics, Centre for Economic and Regional Studies, Hungarian Academy of Sciences. She received her PhD in 2011 in Ecology, Conservation Biology, Taxonomy at the Eötvös Loránd University. She obtained a second master degree in 2010 in Regional and Environmental Economics at the Corvinus University of Budapest. She focuses on the use of biodiversity-related aspects and ecological models in agricultural economic modelling frameworks. Another key research area of hers is the analysis of local food systems and short food supply chains (especially farmers' markets and other market types), with a special focus on the environmental impact of these systems.

Imre Fertő is a Senior Advisor, Director and Head of Agricultural Economics and Rural Development Unit at the Institute of Economics of the Hungarian Academy of Sciences in Budapest. He received his Ph.D. in Economics at the Hungarian Academy of Sciences in 1996, and Ph.D. in Agricultural Economics at the University of Newcastle upon Tyne in 2005 and DSc. in Economics at the Hungarian Academy of Sciences in 2007. Recently, his research focuses on international trade and price transmission, production efficiency, vertical coordination along food chain. He has participated in numerous international research projects sponsored by the Commission of the European Union, the World Bank and the bilateral research programme within framework of Hungarian Academy of Sciences. He is also member of editorial board of various journals including: Industrial Data Management Systems, Agricultural and Food Economics, International Journal of Sustainable Economy, Danube Law and Economics Review, Society and Economy. He is a member of executive board of the European Association of Agricultural Economists and a member of the scientific advisory board of the Leibniz Institute of Agricultural Development in Transition countries.

Adrienn Molnár obtained a master degree in "Agribusiness" at the University of Debrecen, in 2005, in Hungary. In October 2005 she started as a doctoral researcher at the Ghent University, in Belgium and in August 2010 she obtained an academic degree of Doctor of Applied Biological Sciences. In December 2010, she continued as a postdoctoral researcher at Ghent University. In September 2014 she returned to Hungary and started as a postdoctoral researcher at the Hungarian Academy of Science. She participated in several international research projects (FP7, FP6, SEE etc.). 